\title{
Sciendo
}

\section{The Impact of FDI on Economic Development: \\ The Case of Georgia}

\author{
Vakhtang Charaia \\ Faculty of Economics and Business, \\ Tbilisi State University \\ Chavchavadze Ave. 1, \\ Tbilisi 0178, Georgia \\ Email: vakhtang.charaia@tsu.ge

\section{Archil Chochia} \\ Department of Law, \\ Tallinn University of Technology \\ Akadeemia tee 3, \\ Tallinn 12618, Estonia \\ Email: archil.chochia@taltech.ee

\section{Mariam Lashkhi} \\ Faculty of Business Administration, \\ Georgian Aviation University \\ Ketevan Tsamebuli Ave. 16, \\ Tbilisi 0103, Georgia \\ Email: mariam.lashkhi09@gmail.com
}

\begin{abstract}
From the strategic point of view, not all foreign direct investments (FDI) are always positively benefiting the host economy, i.e. not all multinational enterprises (MNEs) are promoting local host economies. Even more, not all FDIs are equally beneficial to different sectors within the same economy. The fact is that FDI can impact different sectors in various ways, and the impact is not only based on the amount of FDI itself but on MNEs' motivations and the peculiarities of the host economy, which can differ from country to county. In other words, only FDI numbers aggregated per year are not really giving a comprehensive picture of the situation and in many cases lead to incorrect strategic decisions, as it has happened in many countries, including Georgia.
\end{abstract}

Keywords: FDI, Georgia, investment, MNE, Scott-Kennel model 


\section{Introduction}

Foreign direct investment implies a direct or lasting interest in, and control of, an enterprise (Loungani \& Razin, 2001). It normally consists of a bunch of assets, including capital, technology, human resources, and knowledge (Dunning \& Lundan, 1993). However, the motivations and the driving force of multinational enterprises (MNEs) could vary in different countries and across different sectors of the economy. In general, Central and Eastern Europe are attracting more and more relatively higher added value production (such as electronics and engineering), which is characterized by geographic concentration, proximity to customers, and high-quality control demand (Cieslic et al., 2019: Dobrin \& Chochia, 2016). These fields are attracting efficiency-oriented FDIs, while South-East Europe and Turkey are attracting FDIs in areas such as textile, food processing, and other relatively low-tech service market-oriented fields (OECD, 2008).

Figure 1. FDI inflow in Georgia, 2007-2018

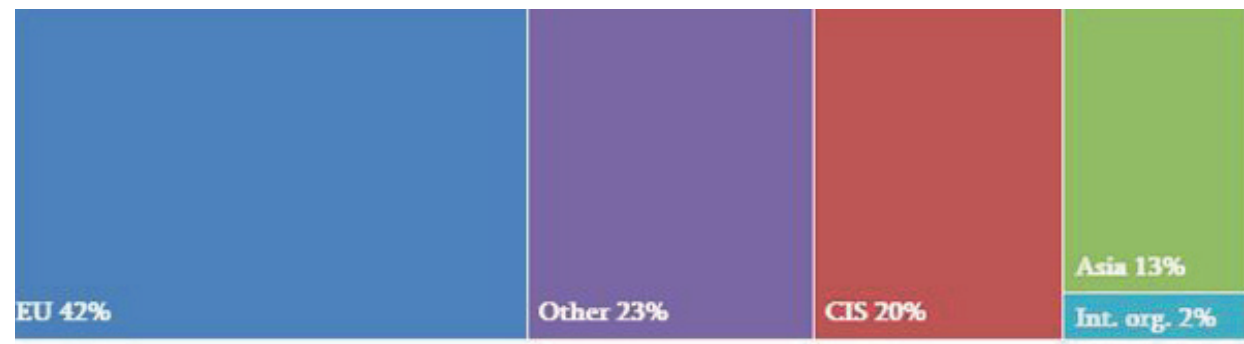

Source: National Statistics Office of Georgia, n.d.

It is important to underline that the EU is the biggest investor in Georgia with more than $40 \%$ of total investments made during the last decade (see Fig. 1). At the same time, Azerbaijan is the leader country in making investments for the same period (Fig. 2); it is mainly interested in infrastructural projects to diversify its hydrocarbon resources transportation through Georgia. There is also a new emerging player-China, with already quite a significant amount of investments (almost 700 million US dollars in the last decade), huge potential and opportunities in nearly all sectors of Georgia's economy, especially under its One Belt, One Road global initiative and free trade regimes already signed between China-Georgia and EU-Georgia (Charaia et al., 2018). 
Figure 2. FDI inflow by country, 2007-2018

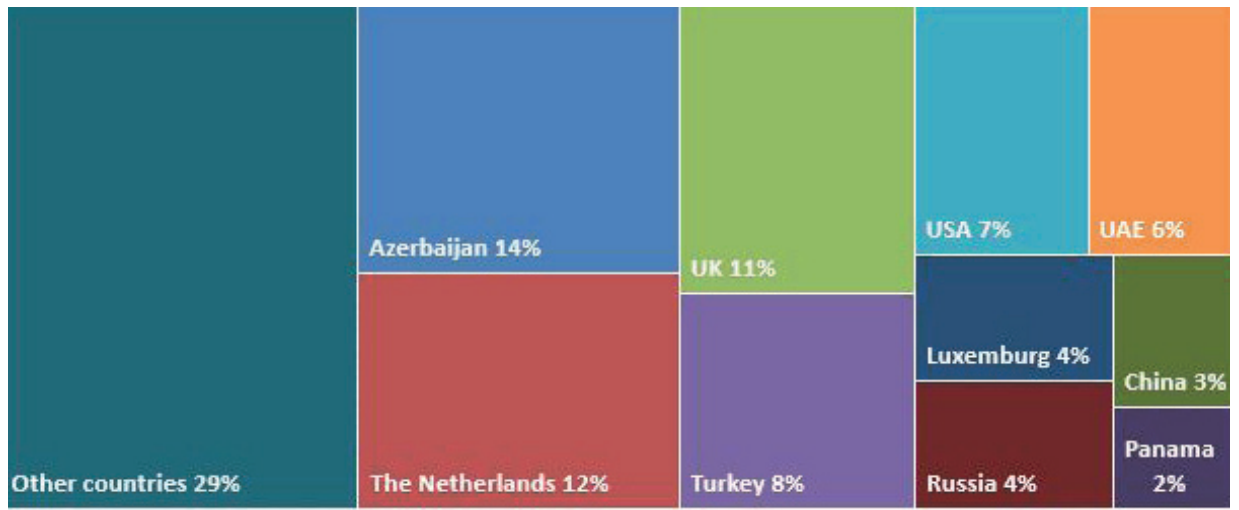

Source: National Statistics Office of Georgia, n.d.

Based on the different countries' interests in Georgia, which could vary from very primitive to high-tech industries, from local resource obtaining to geostrategic positioning, other sectors that get FDIs in Georgia are highly diversified, including the energy, transport, financial, real estate and other sectors (see Fig. 3). Even a marijuana production business was under consideration to benefit the investor, but the idea was turned down following protests among the local population (Papava, 2019). Also, it is important to underline that the share of high-tech industries is relatively small (Pirveli, 2020), even despite the fact that Georgia has the biggest solar panel plant in Europe and it is one of the rare countries in which electric cars are going to be produced already in 2020, and there are some other relatively minor innovative companies.

Figure 3. FDI inflow by sectors, 2007-2018

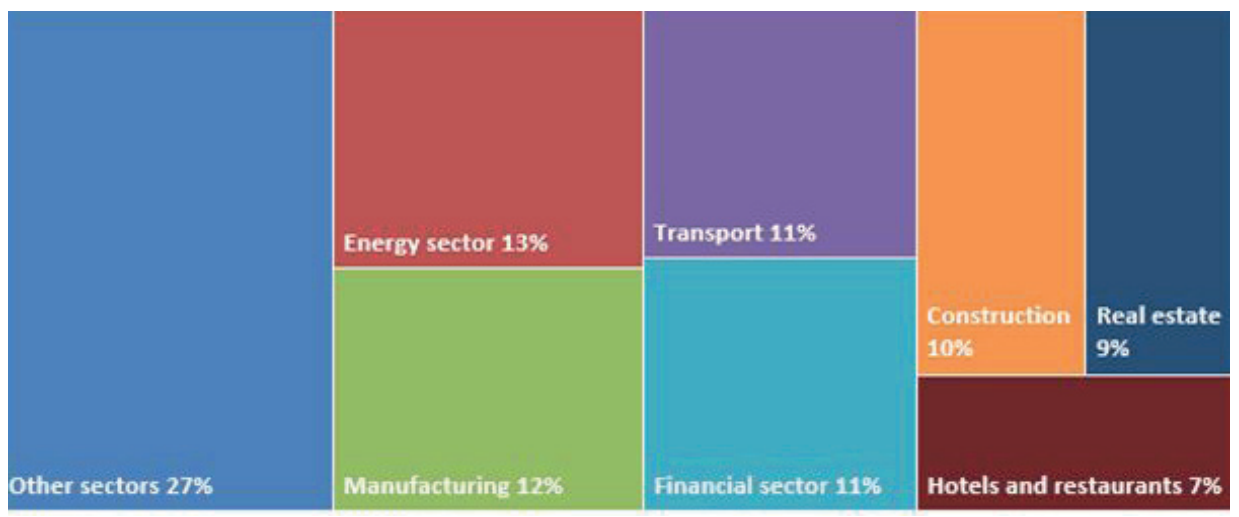

Source: National Statistics Office of Georgia, n.d. 
The last but not least important issue and challenge is that the majority (81\%) of FDIs in Georgia are directed to its capital city-Tbilisi. Two largest regions of Georgia combine a total of $90 \%$ of all FDIs in Georgia (Fig. 4). Unfortunately, this has had its own impact on the country's uneven development, viewed through the regional prism, and causes investment hunger in the regions and pushes the rural population to the capital city.

Figure 4. FDI by regions, 2007-2018

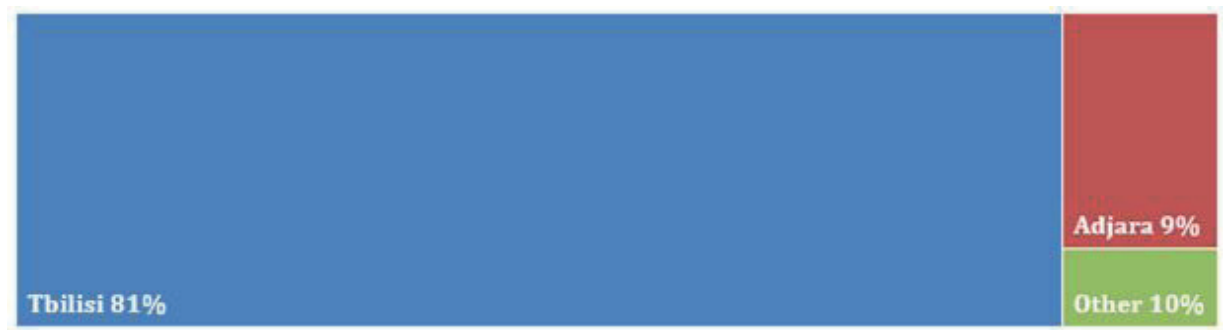

Source: National Statistics Office of Georgia, n.d.

Georgia is one of the post-Soviet countries in which FDIs have played a tremendous role in the transformation of the host economy for the last 20 years (Gürsoy \& Kurşun, 2008; Chochia \& Popjanevski, 2016). However, there are still a lot of questions for which answers are not on the horizon. The questions are very simple but need to answer what are the MNEs' motivations and their influence on Georgia's economy? How much is it facilitating the development and modernization of different economic sectors? And what is the level of integration between MNEs and various sectors of Georgian economy. In this article, the authors attempt to address these specific questions.

\section{The eclectic paradigm of FDI}

Based on the eclectic paradigm proposed by John H. Dunning, motivations of FDI are categorized into resource-based, market-seeking, efficiency-seeking, and strategic asset-seeking motivations (Dunning, 2002). Each of them has a different impact on the host economy, and each of them is characterized by a different level of economic development and economic integration into global markets. 
The goal of the host economy is to get as many benefits as possible out of the MNEs' created assets (Crespo, 2007). However, it has very much depended on both the local government policy and MNEs' motivation. The less there is a connection between the host economy and an MNE, the less apparent it becomes what the host economies benefit from the FDIs, i.e. FDIs have a chance to improve the competitiveness of the host economy (Hunya, 2000) but its impacts are different:

- In host economies with unfavourable characteristics, such as lower GDP per capita or a low level of education, higher total FDI stocks tend to be associated with lower subsequent growth. Generally, it seems to be much easier to attract FDI than to derive macroeconomic benefits from FDI (Stephen, 2007);

- Countries with highly qualified human resources will benefit more from transmitting MNEs' business-related modern technologies;

- The openness of the economy is vital since MNEs follow the complex integrity strategy, i.e., elimination of restrictions for intermediary products at all levels of the production cycle;

- Transfer of technologies is widely dependent on the institutional development of the host economy.

All of the abovementioned factors are closely related to the FDI motivations and have different growth effects on the host economy. For instance, marketseeking FDI provides the host economy with technological assistance and staff training. Also, modern technologies and the import of intermediate products offer additional benefits to the local economy. Finally, the rising competitiveness is pushing local firms to innovation (Charaia, 2014); otherwise, the "crowded out" effect is expected, since international firms are highly competitive (Sikharulidze, 2018). Market-seeking FDIs oriented on conquering local markets are less involved in export-oriented activities (Aggarwal, 2005). In the long run, this could result in a crisis for the balance of payments, since such FDIs cannot provide an inflow of financial assets from export-oriented activities.

Scott-Kennel (2001) argues that the quality of linkages is positively related to the degree of linkage (DOL) of the affiliate in the local industry. In other words, if the quality of linkages is higher, the affiliate is more integrated with the local economy and the DOL is higher.

Countries with unfavorable characteristics are hardly attracting marketoriented FDIs (Liao, 2015) in the service sector in which location attractiveness is determined by the GDP per capita parameter. However, if we consider the 
distribution in the case of Georgia, it is obvious that the service sector is one of the dominant sectors in terms of FDI attractiveness, and so are financial and energy sectors, trade and tourism, transport and communications; all that has taken place in Georgia in respective sectors in the past decades owing to the privatization process. However, market-oriented investments in Georgia's service sector are less efficient in terms of economic growth and exports; they are characterized as having limited capabilities.

Resource-seeking FDIs are attracting mainly large sums of capital inflows, are promoting technological upgrade and transfer of knowhow (Wadhwa, 2011), and also providing the economy with stable currency inflows. Such investments are most often concentrated in the enclave formations, with weak ties to the local commodity and labor markets. Also, one of the negative side effects could be the corruption promotion on macro level by the local elite (Brouthers, 2008). Resource-seeking FDIs can cause the "infection" of "the Dutch decease", although such FDIs are good for promoting foreign trade.

Despite the fact that Georgia's GDP per capita parameter does not seem to be very attractive (4763.5 US dollars in 2019, according to GEOSTAT), it is still attracting market-seeking (natural resources) investments. According to the research done by one of the authors on macro level, it is evident that investments done during 2007-2015 are mostly market-oriented investments-60\%, with efficiency-seeking investments occupying the second place- $36 \%$, and resource-seeking investments only the third place with $4 \%$ (Charaia, 2017b). These results are essential to understand the MNE motivations on macro level, however, they are not sufficient to deepen into the micro-level incentives and analyze the impact of those investments on the local economy.

The main problem in the case of FDI analysis is that most of the researches are oriented only on the total amount of the investments and do not seem to be interested in the heterogeneity of different economies. Based on the questions raised, the research was focused on MNE motivations and their impact on different sectors, taking into a consideration the specifications of the host economy. 


\section{Theoretical background}

To meet the needs of research goals, a well-known Scott-Kennel's (2001) model of local industry upgrading was used, which was based on the case of Georgia and which applied the framework of the IDP on the micro level. The model proposed a typical process of local asset augmentation, as well as the contribution of inward FDI to industrial development as a continuum from enclave to full integration. The model is concentrated on direct and indirect linkages, created by MNEs with local companies, thus having possibilities to modernize local companies and the whole sectors (Scott-Kennel, 2005).

Qualitative methods have been defined as procedures for coming to terms with the meaning rather than the frequency of a phenomenon by studying it in its social context (Van Maanen, 1983). Qualitative methods are particularly well suited to new research areas (Eisenhardt, 1989) and are appropriate when the requirement is to build new theories, synthesize existing theories (Ragin, 1989) or develop a theoretical framework which can then be subjected to hypothesis testing and quantitative analysis.

Ghauri (2004) says that case-study methodology is practical for getting an insight into the problem. It involves data obtained from several sources. This approach relies on the integrative powers of research; the ability to learn an object with many dimensions and then to draw the various elements together into a solid explanation (Selltiz, 1976).

Case studies are chosen as a research tool to analyze the direct and indirect connections of MNEs and local companies/industries, through which their (local companies/industries) modernization could be achieved (Voss, 2010). It is also important to analyze the factors which could affect the final modernization. Therefore, research should be done simultaneously on MNEs' investment activities and their cooperation with local companies/industries.

Ragin (1989) argues that the case-study methodology is inadequate in terms of the difficulty in maintaining attention to complexity across a significant amount of cases. He claims that 8 cases are a "modest number" and 20 cases are "thorough" (Ragin, 1989, p. 20). Consequently, 20 cases were chosen from the fields which have been most attractive for FDIs during the last decades: financial and energy sectors, trade and tourism sectors, transport and communications. Since the cases were from different sectors, during the analysis, special attention was devoted to the correct linkages between them. 
Data were collected by self-administered questionnaires, prepared according to Scott-Kennel's model in 2018-2019. The questionnaires lasted for approximately 60 minutes each, in Georgian, English or Russian languages, depending on the preferences of the respondent. The questionnaire included different sections in which respondents were asked to evaluate the business environment, issue of competitiveness, linkage formation, innovation implementation and other important aspects of Georgia's economy and MNEs' influence on it. The study was carried out among the companies from the list of top 200 foreign investor companies in Georgia.

\section{Results}

As Figure 5 shows, the highest number of investor companies questioned were offshore companies, while other important investor countries were Azerbaijan, Germany, and China.

Figure 5. FDI country of origin (based on respondents' background)

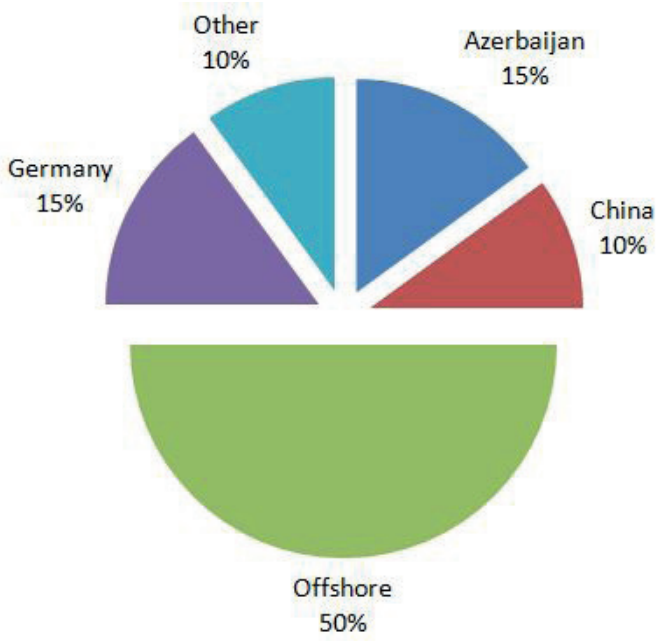

It is important to underline that the vast majority of MNEs were satisfied by their investment and presence in Georgia. Only 5\% of respondents believe that their investment decision was wrong because of different reasons (see Fig. 6). 
Vakhtang Charaia, Archil Chochia

Mariam Lashkhi

Figure 6. Investment satisfaction rate

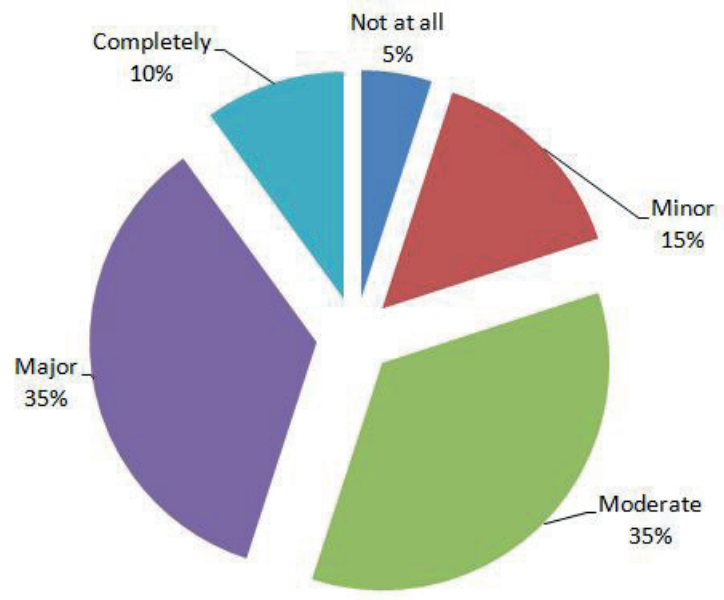

Forty per cent of companies were employing 40 or fewer persons, while $60 \%$ of companies were employing more than 41 people, small companies with up to 20 persons were not presented in the survey (see Fig. 7).

Figure 7. Number of full-time employed personnel

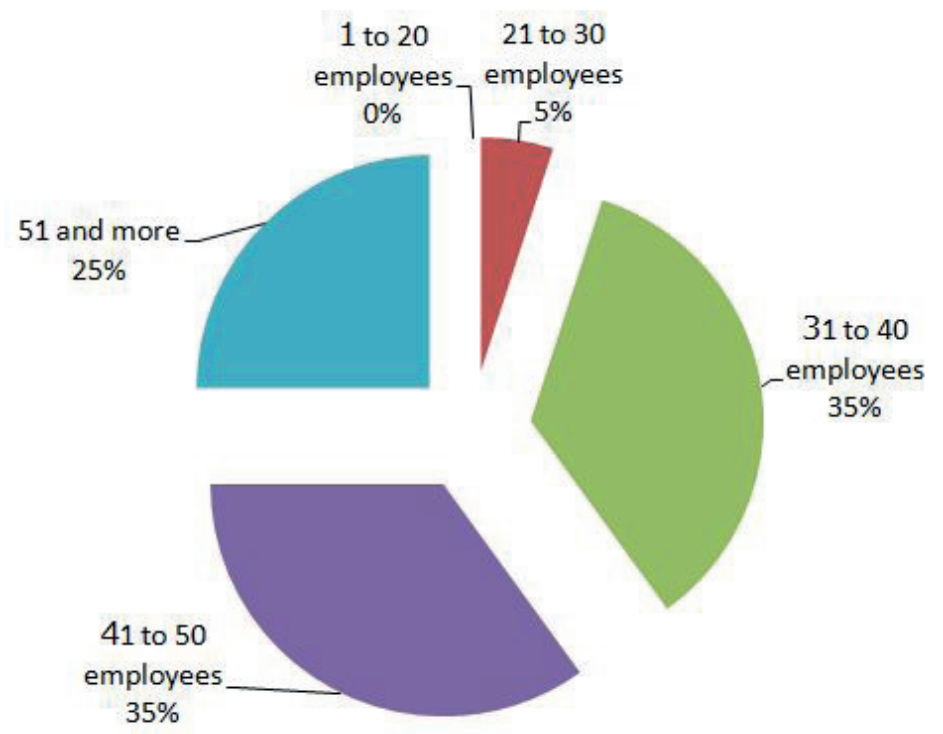

Of the companies, $75 \%$ were training their staff abroad, mainly because of a lack of proper infrastructure (variety and quality of courses, the availability of specific equipment and infrastructure, the low level of educational 
programs, etc.) in the host country (see Fig. 8). At the same time, it is worth mentioning that $100 \%$ of all the companies had implemented labor security management, which is a novelty for local companies, but an important aspect of operation for foreign companies.

Figure 8. Staff training indicator

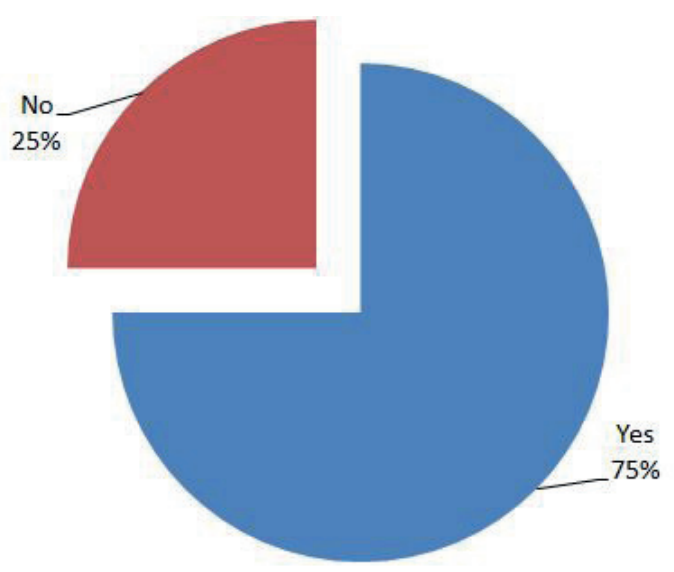

The respondents were asked to name the most important obstacles and opportunities in doing business in Georgia. Each question was evaluated from 0 to 5 points. The highest mean score was for the most significant obstacle or the biggest opportunity.

Table 1. Obstacles in doing business in Georgia

\begin{tabular}{|l|c|c|c|c|}
\hline & Min & Max & Mean & Std. Dev. \\
\hline $\begin{array}{l}\text { Macroeconomic instability (inflation, } \\
\text { exchange rate, etc.) }\end{array}$ & 3 & 5 & 4.4 & 0.73 \\
\hline $\begin{array}{l}\text { Skills and education of available } \\
\text { workers }\end{array}$ & 2 & 5 & 4.2 & 0.89 \\
\hline Cost of finance (interest rate) & 2 & 5 & 4.1 & 0.87 \\
\hline Political instability & 1 & 4 & 3.5 & 0.82 \\
\hline Justice inefficiency & 1 & 4 & 3.4 & 0.78 \\
\hline Innovation and sophistication & 0 & 5 & 3.2 & 1.26 \\
\hline Infrastructure & 2 & 5 & 2.5 & 0.85 \\
\hline Access to land & 0 & 2 & 1.8 & 0.39 \\
\hline Labor regulations & 0 & 5 & 1.8 & 1.45 \\
\hline Crime, theft, and disorder & 0 & 1 & 0.4 & 0.21 \\
\hline
\end{tabular}

Macroeconomic instability was named as the biggest obstacle (see Table 1). Unfortunately for Georgian economy and investors, in particular, 
the exchange rate instability has become the biggest problem for foreign investors in Georgia, since it became problematic to plan the budget, prices, salaries, logistics, etc. Since the devaluation process was started in late 2014, Georgian national currency Lari has been devaluated by around 60\% to 2.6 Gel per US dollar, but even bigger problems derive from the main trading partners (Turkey, Russia, Ukraine, Azerbaijan, etc.) devaluating local currencies by two, three and even more times.

The skills and education of available workers were named as the second major problem. Despite the fact that this problem has been known for many years, there has been no significant improvement in this direction so far. According to different international organizations and international rankings, this issue is declared as one of the most significant obstacles in doing business in Georgia. The roots of this problem are hidden deep in the educational system and the mindset of Georgians. Older-generation scientists are still famous in Georgia, but at the same time, the qualification and opportunities of the majority of these scientists today are below the world average. Thus, occupying the leading positions in different universities, the majority of older-generation scientists with their lack of knowledge and little experience in modern science trends are not ready to hand the power over to the younger generation, refusing even to cooperate with them. The factors affecting young researchers' future professional orientation are not well studied in Georgia (Kvirkvaia, 2018). One of the lowest mean scores was attributed to the crime level, which is evidence that Georgia is one of the safest places to do business with low criminal level and high trust in police.

Table 2. Advantages of doing business in Georgia

\begin{tabular}{|l|c|c|c|c|}
\hline & Min & Max & Mean & Std. Dev. \\
\hline $\begin{array}{l}\text { Ease and speed of } \\
\text { interaction with bodies of } \\
\text { government }\end{array}$ & 3 & 5 & 4.3 & 0.75 \\
\hline $\begin{array}{l}\text { Ease and speed of } \\
\text { different procedures }\end{array}$ & 3 & 5 & 4.2 & 0.71 \\
\hline $\begin{array}{l}\text { Business licensing and } \\
\text { operating permits }\end{array}$ & 3 & 5 & 4.1 & 0.70 \\
\hline Tax rates & 2 & 5 & 3.9 & 0.84 \\
\hline Labor force & 0 & 5 & 3.7 & 1.31 \\
\hline Corruption & 1 & 4 & 3.5 & 0.75 \\
\hline Access to finance & 0 & 4 & 3.2 & 1.19 \\
\hline $\begin{array}{l}\text { Customs and trade } \\
\text { regulations }\end{array}$ & 0 & 5 & 3.0 & 1.19 \\
\hline
\end{tabular}


The part of the questionnaire related to the opportunities was also interesting (see Table 2). This involved responses to the question: Which aspects of the FDI policy positively influence the way your firm operates in Georgia? Ease of interaction with bodies of government presented the highest mean scores.

Low corruption (Georgia ranks 44th in the world according to the Corruption Perception Index) and tax rates (the country ranks 9th among the low tax rate economies according to the WEF Global Competitiveness Report), which implies special favorable tax regimes and $0 \%$ tax on reinvestment profit, were also defined as one of the main advantages for doing business in Georgia. Access to finance was named as one of the least positive aspects, though still an advantage, which is quite controversial in view of the business society in Georgia in general. This could be explained by the fact that the companies questioned were MNEs, which, as a rule, are not dependent on local financing opportunities.

Customs and trade regulations are an important factor for companies aiming to settle down in Georgia to operate in the whole region. For instance, this particular reason was crucial for Toyota. Simultaneous free trade agreements with the EU and China make Georgia one of the unique countries in the world and could promote not only Georgia, but also the EU, US and Chinese economies as well (Lashkhi, 2018; Charaia, 2017a; Papava, 2017; Wang, 2018).

According to many investors, labor force in general is an obstacle for doing business in Georgia; however, in this case, many local market-seeking MNEs were quite satisfied with the situation. For many MNEs it was important to have motivated youngsters with knowledge of foreign languages and readiness to work for a lower salary than in developing countries or even starting an internship, the opportunities for which are readily available in Georgia.

Based on the data collected we also carried out a factor analysis to find out if the measured variables can be explained to a larger degree in terms of a much smaller number of variables (factors), i.e. we divided all variables into three main factors both for obstacles and opportunities in doing business in Georgia. Namely, the main factors for obstacles were regulation, infrastructure and stability, and for opportunities-speed and price. The analysis yielded interesting results which are important for policymaking. 
Table 3. The most important obstacles for MNEs in Georgia

\begin{tabular}{|l|c|c|}
\hline & Mean & Std. Dev. \\
\hline $\begin{array}{l}\text { Stability (economic, political, } \\
\text { social) }\end{array}$ & 3.64 & 0.77 \\
\hline $\begin{array}{l}\text { Infrastructure (physical, social, } \\
\text { criminal) }\end{array}$ & 3.19 & 0.72 \\
\hline $\begin{array}{l}\text { Regulations } \\
\text { (licenses and access) }\end{array}$ & 2.65 & 0.67 \\
\hline
\end{tabular}

Based on the results, it is clear that macroeconomic stability is the number one problem for foreign companies (and also for local ones), since it affects the price and therefore the competitiveness of their products.

Table 4. The most significant opportunities for MNEs in Georgia

\begin{tabular}{|l|c|c|}
\hline & Mean & Std. Dev. \\
\hline Speed & 3.8 & 0.52 \\
\hline Price & 3.7 & 0.69 \\
\hline
\end{tabular}

On the other hand, the investors say that the speed and price of doing business in Georgia is highly positive (see Table 4) and, if we measure its efficiency, it equals $75 \%$ satisfaction, which would be a good asset to attract additional FDIs for any developing country. However, some other important aspects named as an obstacle for doing business in Georgia should also be modified.

MNEs are creating new workplaces, contribute to the local production and export diversification, pay taxes and participate in many other central aspects of economic life in Georgia. However, the quality of linkage of MNEs with the local companies is so far at a low level. Only $10 \%$ of the resources transferred to local firms were unique (see Fig. 9), while the share of nonunique resources equaled $90 \%$. 
Figure 9. Resource transfer from MNEs to local companies

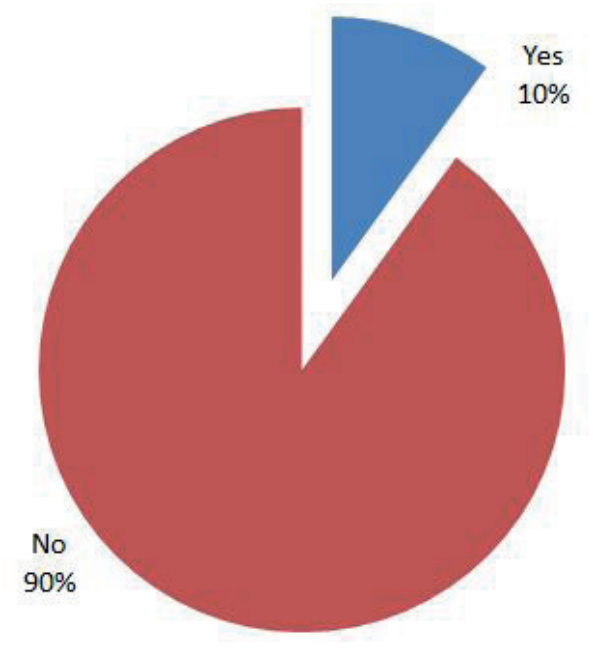

On the other hand, MNEs are claiming that they are actively assisting local companies (85\%) to improve their products or services, which, by the way, could be later used by those MNEs as well (see Fig. 10), for instance, to get cheaper and/or higher quality products on the spot rather than to order them from abroad as was the case of training local staff locally or abroad.

Figure 10. MNEs assistance in local product improvement

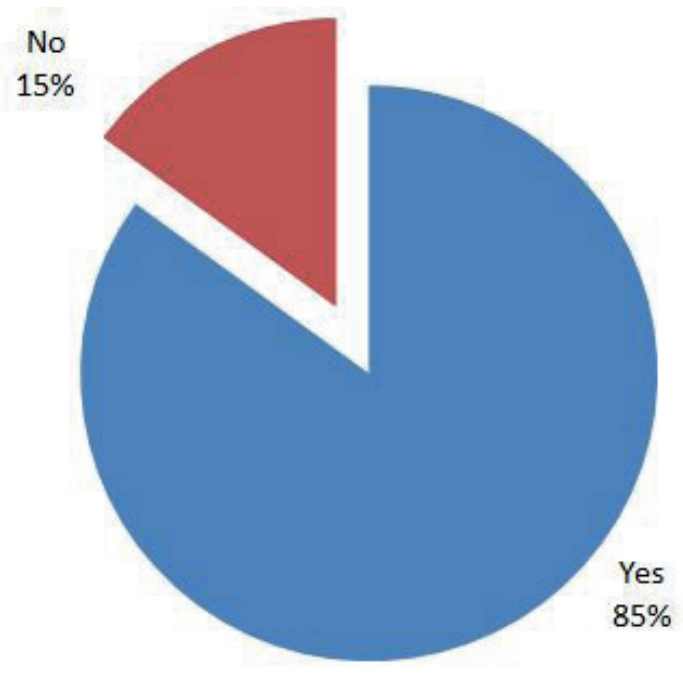


Compared to the 1990s, the motivation structure of foreign companies investing in Georgia has changed drastically, moving from local resourcebased, towards more market- and efficiency-seeking ones. However, the percentage of companies investing in Georgia for the strategic asset-seeking purpose is still zero (see Table 11), which is a big challenge for Georgia and could be explained by a lack of skilled workforce, digitalization level, systemic political instability and other issues.

\section{Figure 11. MNEs' motivations in Georgia}

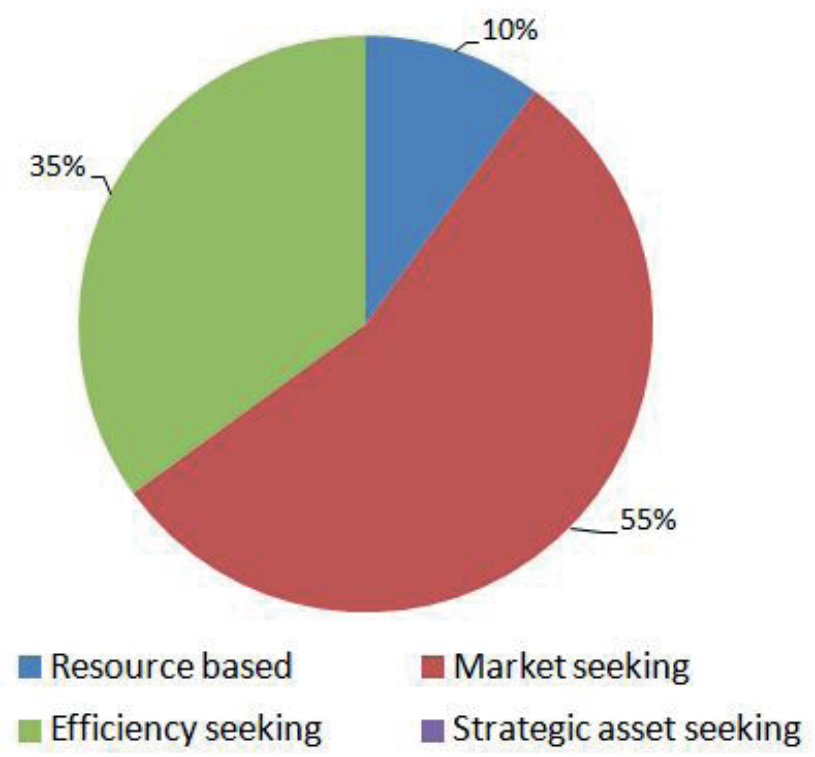

The responses to the question whether the company's operations in Georgia have influenced the changes (see Fig. 12) were "At the moderate level" (75\%), while only a few responded "Not at all" (5\%) or "Minor" (10\%) or "Major" $(10 \%)$.

Scott-Kennel (2001) has argued that the quality of linkages between MNEs and the local economy is positively related to the degree of linkage; thus the higher DOL brings more benefits. However, the degree of linkage between MNEs and the host economy in case of Georgia is considerably low at this stage of development, which is not a surprise. Still, it has a positive trend on the country's economic development (Charaia, 2018). 
Figure 12. MNEs' influence on change

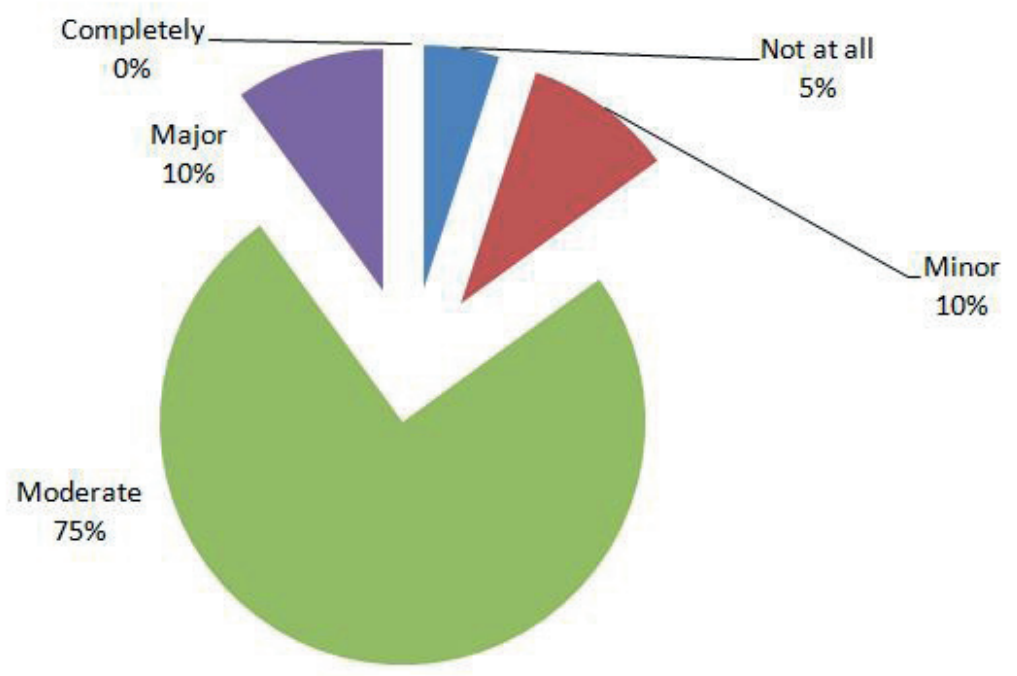

\section{Conclusion}

At the beginning of the article, several questions were put forth: What are the MNEs' motivations and influence on the Georgian economy? How much are they assisting development and modernization? Also, what is the level of integration between MNEs and the Georgian economy? After reviewing the data, despite the fact that the level of their integration and the quality of their presence has remained average so far, we can say that MNEs play an important role in Georgia's economic development. Considering the economic development of Georgia and the opportunities it can provide to MNEs, we may argue that the country is on the right path and more benefits supporting Georgia's economic transformation are expected to appear for both sides. 


\section{Acknowledgements}

This research was supported by Shota Rustaveli National Science Foundation of Georgia (SRNSFG) [grant number YS-19-154] and by a Marie Curie Research and Innovation Staff Exchange scheme within the H2020 Programme (grant acronym: SHADOW, no: 778118).

Vakhtang Charaia, PhD is associated professor at Grigol Robakidze University and head of TSU Center for Analysis and Forecasting. At different times he studied and conducted his PhD research at Tbilisi State University (Georgia), Passau University, University of Bremen (Germany), European University at St. Petersburg (Russia), the Institute of Government Accounts and Finance (India), University of Tartu (Estonia), and George Washington University (USA). Prof. Charaia has published more than 30 scientific articles in peer-reviewed academic journals, several books and chapters in different books. He is the Best Young Scientist (Economist) of Georgia for the year 2018. His research fields are free trade regimes, foreign direct investment, international trade, peacebuilding and conflict resolution.

Archil Chochia, PhD is researcher at TalTech Law School of Tallinn University of Technology. Dr. Chochia obtained his doctoral degree from Tallinn University of Technology in 2013, while he has previously studied at Tbilisi State Medical University, as well as completed short study programmes at the University of Scranton, University of California, Pepperdine University and Harvard University. He has more than 80 academic publications as articles in peer-reviewed academic journals, chapters in books, doctoral dissertation and conference papers. He is a coeditor of the books Political and Legal Perspectives of the EU Eastern Partnership Policy (Springer, 2016) and Brexit: History, Reasoning and Perspectives (Springer, 2018). Chochia is a senior fellow of the Weinstein International Foundation.

Mariam Lashkhi is visiting lecturer at Georgian Aviation University and researcher at TSU Center for Analysis and Forecasting. She has graduated from Tbilisi State University and is actively involved in (economic) research projects often published on different analytical platforms. Mariam Lashkhi has participated in various local and international conferences and published several articles in peer-reviewed academic journals. 
Her research interests are China-Georgia-EU economic cooperation, international economic relations, the economics of developing countries and foreign direct investments.

\section{References}

Aggarwal, A. (2005), 'The influence of labour markets on FDI: some empirical explorations in export oriented and domestic market seeking FDI across Indian states,' in Competitive Section of the Global Conference on Business and Economics, held at the Oxford University, London, pp. 25-27.

Brouthers, L. E.; Gao, Y. \& McNicol, J. P. (2008), 'Corruption and market attractiveness influences on different types of FDI,' Strategic Management Journal, vol. 29, no. 6, pp. 673-680. https://doi.org/10.1002/smj.669

Cieślik, E.; Biegańska, J. \& Środa-Murawska, S. (2019), 'Central and Eastern European states from an international perspective: economic potential and paths of participation in global value chains,' Emerging Markets Finance and Trade, pp. 1-17. https://doi.org/10.1080/1540496X.2019.1602519

Charaia, V. (2014), 'Local investment climate and the role of (sustainable) FDI: the case of Georgia,' International Journal of Social, Behavioral, Educational, Economic, Business and Industrial Engineering, vol. 8, no. 2, pp. 425-428. Retrieved from http://waset.org/publications/9997562/local-investmentclimate-and-the-role-of-sustainable-fdi-the-case-of-georgia [accessed Jun 2020]

Charaia, V. (2017a), Trade and Investment Relations between Georgia and China, Expert Opinion, Georgian Foundation for Strategic and International Studies, pp. 3-13. Retrieved from https://www.gfsis.org/files/library/opinion-papers/94expert-opinion-eng.pdf [accessed Jun 2020]

Charaia, V. (2017b), 'The role of multinational enterprises' investments in emerging country's economic development, case of Georgia,' World Academy of Science, Engineering and Technology, International Journal of Social, Behavioral, Educational, Economic, Business and Industrial Engineering, pp. 697-700. Retrieved from http://www.waset.org/publications/10006953 [accessed Jun 2020]

Charaia, V. (2018), 'FDI motivation and benefits for Georgia,' Ekonomisti, no. 1, pp. $47-53$.

Charaia, V.; Chochia, A. \& Lashkhi, M. (2018), 'The Caucasus 3 plus the Baltic 3 and economic cooperation with China,' Baltic Journal of European Studies, vol. 8, no. 2, pp. 44-64. https://doi.org/10.1515/bjes-2018-0015 
Chochia, A. \& Popjanevski, J. (2016), 'Change of power and its influence on country's Europeanization process. Case study: Georgia,' in T. Kerikmäe \& A. Chochia (eds.) Political and Legal Perspectives of the EU Eastern Partnership Policy, Cham: Springer International Publishing, pp. 197-210. https://doi.org/10.1007/978-3-319-27383-9_13

Crespo, N. \& Fontoura, M. P. (2007), 'Determinant factors of FDI spilloverswhat do we really know?' World Development, vol. 35, no. 3, pp. 410-425. https://doi.org/10.1016/j.worlddev.2006.04.001

Dobrin, S. \& Chochia, A. (2016), 'The concepts of trademark exhaustion and parallel imports: a comparative analysis between the EU and the USA,' Baltic Journal of European Studies, vol. 6, no. 2, pp. 28-57. https://doi.org/10.1515/bjes-2016-0011

Dunning, J. H. (2002), Theories and Paradigms of International Business Activity, vol. 1, Cheltenham: Edward Elgar Publishing Ltd. https://doi.org/10.4337/9781843767053

Dunning, J. H. \& Lundan, S. M. (1993), Multinational Enterprises and the Global Economy, Wokingham: Addison-Wesley Publishing Company.

Eisenhardt, K. (1989), 'Building theories from case study research,' Academy of Management Review, vol. 11, no. 4, pp. 533-550. https://doi.org/10.5465/ amr.1989.4308385

Ghauri, P. (2004), 'Designing and conducting case studies in international business research,' Handbook of Qualitative Research Methods for International Business, Cheltenham: Edward Elgar Publishing Ltd., pp. 109-124. https://doi.org/10.4337/9781781954331.00019

Gürsoy, P.; Kurşun, O. (2008), 'Investment climate of Georgia,' IBSU Scientific Journal (IBSUSJ), vol. 2, no. 1, pp. 71-79.

Hunya, G. (2000), International Competitiveness Impacts of FDI in CEECs, wiiw Research Report, no. 268, The Vienna Institute for International Economic Studies.

Kvirkvaia, M.; Kikutadze, V.; Sikharulidze, D.; Shaburishvili, S. \& Charaia, V. (2018), 'Study of factors affecting young people's professional orientation in Georgia,' Globalization \& Business, pp. 233-242.

Lashkhi, M. \& Charaia, V. (2018), 'An analysis of the motives underlying foreign direct investments (the case of Georgia),' Central Asia \& the Caucasus, vol. 19, no. 4 .

Liao, T. J. (2015), 'Clusters, technological knowledge spillovers, and performance: the moderating roles of local ownership ties and a local market orientation,' Management Decision, vol. 53, no. 2, pp. 469-490.

https://doi.org/10.1108/MD-09-2014-0560 
Loungani, P. \& Razin, A. (2001), 'How beneficial is foreign direct investment for developing countries?' Finance \& Development, vol. 38, no. 2, pp. 6-9.

National Statistics of Georgia (n.d.), [Home page]. Retrieved from https://www. geostat.ge/en [accessed June 2020]

OECD (2008), OECD Environmental Performance Reviews: Turkey, Paris: OECD Publishing. https://doi.org/10.1787/9789264049161-en

Papava, V. \& Charaia, V. (2017), 'Belt and Road Initiative: implications for Georgia and China-Georgia economic relations,' China International Studies, pp. 122-137. https://doi.org/10.2139/ssrn.3325126

Papava, V.; Charaia, V. \& Tsopurashvili, G. (2019), 'What will the marijuana economy give to Georgia?' GFSIS Expert Opinion, no. 114. Retrieved from https://www.gfsis.org/files/library/opinion-papers/114-expert-opinion-eng.pdf [accessed Jun 2020]

Pirveli, E.; Shugliashvili, T. \& Machavariani, N. (2020, forthcoming), 'Rethinking economic policy of Georgia in the times of COVID-19,' International Journal of Economic Policy in Emerging Economies.

Ragin, C. (1989), The Comparative Method: Moving Beyond Quantitative and Qualitative Strategies, London: University of California Press.

Scott-Kennel, J. E. (2001), The Impact of Foreign Direct Investment on New Zealand Industry, Unpublished PhD thesis, New Zealand.

Scott-Kennel, J. E. (2005), Foreign Direct Investment and Inter-Firm Linkages: Exploring the Black Box of the Investment Development Path, UNCTAD/ITE/ IIT, no. 14, pp. 105-137.

Selltiz, C. W.; Wrightsman, L. S. \& Cook, S. W. (1976), Research Methods in Social Relations, New York: Holt, Rinehart \& Winston of Canada Ltd.

Sikharulidze, D. \& Charaia, V. (2018), 'Oli paradigm and investment position of Georgia,' Globalization \& Business, pp. 71-78.

Stephen, D. \& Cohen, S. D. (2007), Multinational Corporations and Foreign Direct Investment: Avoiding Simplicity, Embracing Complexity, Oxford: Oxford University Press.

Van Maanen, J. (1983), 'Reclaiming qualitative methods for organizational research: a preface,' Qualitative Methodology, vol. 24, no. 4, pp. 9-18. https://doi.org/10.2307/2392358

Voss, C. (2010), 'Case research in operations management,' in C. Karlsson (ed.) Researching Operations Management, New York: Routledge, pp. 176-209.

Wang, F.; Papava, V. \& Charaia, V. (2018), 'China-Georgia economic relations in the context of the Belt and Road Initiative,' Bulletin of the Georgian National Academy of Sciences, vol. 12, no. 1. Retrieved from https://slidego.org/ Engineering/china-georgia-economic-relations-in-the-context-of-the-belt-androad-initiative [accessed Jun 2020] 
Vakhtang Charaia, Archil Chochia

Mariam Lashkhi

Wadhwa, K. \& Reddy, S. S. (2011), 'Foreign direct investment into developing Asian countries: the role of market seeking, resource seeking and efficiency seeking factors,' International Journal of Business and Management, vol. 6, no. 11, pp. 219-226. https://doi.org/10.5539/ijbm.v6n11p219 